\title{
Relationship between Perceived Parenting Skills and Self Esteem among Adolescents
}

\author{
Niraja. $S^{1 *}$, S. Meherunissa ${ }^{2}$
}

\section{ABSTRACT}

This study is to find the relationship of perceived parenting skills (modes), with mothering and fathering impact on the self-esteem of adolescent. This study examines the skill of father, mother, and parental (as whole) influence on the self-esteem of adolescents. The study is based on adolescents' perception of parenting. The study involves a sample of 255 adolescent students selected randomly from two schools in the urban area. The variables in the study were measured by using Parenting Scale (Bharadwaj, Sharma, and Garg, 1998), The Rosenberg Self-esteem Scale (Morris Rosenberg) and demographic details. Statistical analysis was done using statistical package (SPSS), with t-test, ANOVA and Karl Pearsons Correlation. The results showed that parenting styles had significant effects on adolescents' self-esteem. It was also found that girls had a higher level of self-esteem than the boys. However no significant difference was found in the self-esteem of adolescents based on birth order and father's occupation. The implication of the findings is that the type of parental upbringing has significant impacts on the self-esteem of adolescent and therefore, parents and caregivers should ensure the use of best practices in child upbringing.

\section{Keywords: Parenting Skills, Self Esteem, Adolescents}

The task of child rearing is exceedingly difficult in a context of rapid societal change which is reflected in the complexities of changing family structures, the challenge of balancing work life, and in the social and environmental issues that affect communities. Amidst these difficulties the role of parents is to nurture their offspring. The role of parents as sculptors to constitute a child's behaviour which is manifested, learned, encouraged, and suppressed by effective parenting skills. For all social and educational development, the family and parenting style plays an important role.

\footnotetext{
${ }^{1}$ M.Sc Psychology Student, Department of Psychology, JBAS College for Women, Chennai, India

${ }^{2}$ Assistant Professor of Psychology, Department of Psychology, JBAS College for Women, Chennai, India *Responding Author

(C) 2016 Niraja S, Meherunissa S; licensee IJIP. This is an Open Access Research distributed under the terms of the Creative Commons Attribution License (http://creativecommons.org/licenses/by/2.0), which permits unrestricted use, distribution, and reproduction in any Medium, provided the original work is properly cited.
} 


\section{Relationship between Perceived Parenting Skills and Self Esteem Among Adolescents}

Parents attempt to shape, control, and evaluate the behaviour and attitudes of their children in accordance with an absolute set of standards; value obedience, respect for authority, work, tradition, and preservation of order; discourage verbal give and take. Parenting as the style of child upbringing refers to a privilege or responsibility of mother and father, together or independently to prepare the child for society and culture (Veenes, 1973a) which provides ample opportunity to a child to find roots, continuity and a sense of belonging (Shiorohi and Chauhan, 1991) and also serves as an effective agent of socialization. Though parenting, as a perception of the parents to their own attitude towards the child, happens to be of great significance in the dynamics of behaviour for socio-psychological researches, but how child perceives his/ her parenting always remains a neglected phase of researches and should be deemed most important as he is the one whose process of socialization stands for furtherance (Bharadwaj, 1996).

Self-esteem in sociology and psychology reflects a person's overall subjective emotional evaluation of his or her worth. It is a judgment of oneself as well as an attitude towards the self. It is the self-evaluative part of the self-concept. Self-esteem is a global self-evaluation that blends many specific evaluations about one's adequacy as a student, an athlete, a worker, a spouse, a parent, or whatever is personally relevant. In western cultures it is considered the bedrock of an individual's success. Smith and Mackie (2007) defined it by saying “The selfconcept is what we think about the self; self-esteem is the positive or negative evaluations of the self, as in how we feel about it."Healthy self-esteem to a child is like a shield against the challenges of the world.

Choi, S., L., Ooi, S. H., and Rabeatul, H. A. R.(2015 AUG) conducted an Analysis on The Relationship between Parenting Styles and Self Esteem of Students of a University in Malaysia (case study).As a conclusion, the results show that permissive parenting style is the dominant parenting style and has positive relationship between authoritative parenting style. The study found that the authoritarian parenting style has a negative relationship with students' self-esteem. Sathyabama, B., and Jeryda, G. J. O. (2014. AUG) studied Perceived Parental Attitude and Self Esteem of Adolescents. The results revealed that there was a significant relationship between parenting and self-esteem of adolescents. Moreover the boys and girls differed in the perception of parenting and in the level of self-esteem.

\section{METHODOLOGY}

The aim of the present study is to find the adolescents perception of their parent's different parenting skill models, in relation to the self-esteem of adolescence with various demographic details.

\section{Objectives of the Study}

1. To assess the difference between adolescents' self-esteem of adolescent based on gender. 


\section{Relationship between Perceived Parenting Skills and Self Esteem Among Adolescents}

2. To investigate the relationship between self-esteem of adolescent and their perception of parenting.

3. To assess the self-esteem of adolescent under different modes of mothering and fathering separately.

4. To assess the self-esteem of adolescent based on birth order.

5. To assess the self-esteem of adolescent based on occupation of father.

\section{Hypothesis}

1. There will be no significant difference in the self-esteem of adolescents based on gender.

2. There will be no significant relationship between the self-esteem and parenting of adolescents.

3. There will be no significant difference between overall parenting of father and mother of adolescence children.

4. There will be no significant difference in the self-esteem of adolescence based on their perception of mothering under different modes:-
A. Rejection vs. Acceptance.
B. Carelessness vs. Protection.
C. Neglect vs. Indulgence.
D. Utopian Expectation vs. realism.
E. Lenient Standard vs. Moralism.
F. Freedom vs. Discipline.
G. Faulty role Expectations vs. Realistic Role Expectation.
H. Marital Conflict vs. Marital Adjustment.

5. There will be no significant difference in the self-esteem of adolescence based on their perception of fathering under different modes:-
A. Rejection vs. Acceptance.
B. Carelessness vs. Protection.
C. Neglect vs. Indulgence.
D. Utopian Expectation vs. realism.
E. Lenient Standard vs. Moralism.
F. Freedom vs. Discipline.
G. Faulty role Expectations vs. Realistic Role Expectation.
H. Marital Conflict vs. Marital Adjustment.

6. There will be no significant difference in the self-esteem of adolescents between $1^{\text {st }}, 2^{\text {nd }}$, and $3^{\text {rd }}$ birth order.

7. There will be no significant difference in the self-esteem of adolescents whose fathers' occupations are categorised as self-employed, or white collar job, or blue collar job. 


\section{Relationship between Perceived Parenting Skills and Self Esteem Among Adolescents}

\section{Research Design:}

This study is Ex-post Facto research as the research attempts to examine, the relationship between adolescents' perception of parenting skill and their self-esteem at the time of investigation. Primary data was collected by survey method. It is a non-experimental study.

\section{Variables Of The Study}

- $\quad$ Independent variable - Parenting skills.

- $\quad$ Dependent variable - Self-esteem.

\section{Sampling Design}

- A disproportionate stratified random sampling on urbanised adolescent students of both genders was selected for this study.

\section{Sampling Characteristics}

The sample is drawn by survey method from students of P.A.K. Palanisamy Nadarboys higher secondary school and Arumuga Nadar girls higher secondary school. Stratified sampling is done among adolescence students of standard XI, and XII among 3 sections, irrespective of the size of the population or stratum. Sample selected were 300 adolescent urban area students and after exclusion of inappropriate data 254 adolescence students consisted the sample size. Hence 135 male students and 119 female students were selected with similar categorization.

\section{Inclusion/Exclusion Criteria}

\begin{tabular}{|l|l|}
\hline \multicolumn{1}{|c|}{ Inclusion criteria } & \multicolumn{1}{|c|}{ Exclusion criteria } \\
\hline $\begin{array}{l}\text { Adolescents of biologically reared children. } \\
\text { Physically fit adolescents. } \\
\text { Interested participants. }\end{array}$ & $\begin{array}{l}\text { Single parented children. } \\
\text { Children with psychosocial problem. (teacher's } \\
\text { report) } \\
\text { Incomplete data. }\end{array}$ \\
\hline
\end{tabular}

Table shows Sample Characteristics

\begin{tabular}{|l|l|l|l|l|l|l|l|l|l|}
\hline \multicolumn{2}{|c|}{ Gender } & \multicolumn{6}{c|}{ Birth Order } & \multicolumn{2}{c|}{ Occupation of Father } \\
\hline Girls & Boys & $\mathbf{1}$ & $\mathbf{2}$ & $\mathbf{3}$ & $\mathbf{4}$ & $\mathbf{5}$ & $\begin{array}{l}\text { Self } \\
\text { Employed }\end{array}$ & $\begin{array}{l}\text { White } \\
\text { collar }\end{array}$ & $\begin{array}{l}\text { Blue } \\
\text { collar }\end{array}$ \\
\hline 119 & 135 & 141 & 90 & 23 & 2 & 1 & 51 & 72 & 131 \\
\hline
\end{tabular}

\section{Demographic Description}

The age group of the respondents was 16 - 18 years. The average age was 17.5 year. The mothers were mostly unemployed, and most of the fathers were held up at low socio-economic status jobs. Nearly one third of the parents are working as coolies. Domicile of the respondents were from $100 \%$ urban area, as the study was done in urban area. Significant percentage of respondents' family size was 4 to 6 members. Birth order had large number of $1^{\text {st }}$ and $2^{\text {nd }}$ born

(c) The International Journal of Indian Psychology, ISSN 2348-5396 (e)| ISSN: 2349-3429 (p) | 164 
than the $3^{\text {rd }}, 4^{\text {th }}$ and $5^{\text {th }}$ born. In regard to siblings majority of them were 2 . In regard to religion, majority of them were Hindus, and remaining were Muslims and Christians. With regard to birth order, nearly two third were of first birth order and the rest were of second birth order. Majority of the respondents seem to live in nuclear family type.

Tools Used For The Study

Table shows Overview of the tools used in the study

\begin{tabular}{|l|l|l|l|l|}
\hline $\begin{array}{l}\text { SL. } \\
\text { NO }\end{array}$ & $\begin{array}{l}\text { NAME OF THE } \\
\text { TOOL }\end{array}$ & AUTHOR & $\begin{array}{l}\text { VARIABLES } \\
\text { MEASURED }\end{array}$ & $\begin{array}{l}\text { RELIABILITY AND } \\
\text { VALIDITY }\end{array}$ \\
\hline 1 & $\begin{array}{l}\text { Parenting Scale (P } \\
\text { Scale) }\end{array}$ & $\begin{array}{l}\text { Bharadwaj, R. L., } \\
\text { Sharma, H., and } \\
\text { Garg, A., }\end{array}$ & Parenting Skills & $\begin{array}{l}\text { Reliability 0.72 } \\
\text { Validity } 0.75\end{array}$ \\
\hline 2 & $\begin{array}{l}\text { Rosenberg Self- } \\
\text { Esteem scale }\end{array}$ & Rosenberg, M. (1965) & Self-Esteem & $\begin{array}{l}\text { Reliability0.77 } \\
\text { Validity } 0.63\end{array}$ \\
\hline
\end{tabular}

\section{Administration Of The Tools}

After obtaining permission from the principal, the students were given information about the research study, instructions of the questionnaire and trust to maintain confidentiality of their answers. Students, who were willing to participate, were provided with a self-report questioner which exposed their self-esteem, and their perceiving of parental attitude (of both father and mother) towards them. Student's demographic details were obtained through survey.

\section{Statistical Test Used}

The following techniques were used in the study:

1. Descriptive statistics such as mean and standard deviation, and 't'-test were used to determine

- Difference in self-esteem based on gender

- Difference in self-esteem based on mothering and fathering

- Self-esteem based on different modes of mothering

- Self-esteem based on different modes of fathering

2. Karl Pearson's correlation to assess the relationship between parenting and self-esteem.

3. Anova (one way) to find difference in self-esteem based on

- Birth order

- Fathers occupation

\section{RESULTS}

Table shows the variable, Overall adolescents Mean score of high and low Self-Esteem.

\begin{tabular}{|l|l|l|}
\hline Variable & High & Low \\
\hline Self-esteem & 28.39 & 18.00 \\
\hline
\end{tabular}

(c) The International Journal of Indian Psychology, ISSN 2348-5396 (e)| ISSN: 2349-3429 (p) | 165 
Table shows the variable, sample size, Mean, Standard Deviation, ' $t$ ' value and Level of Significance of Self-esteem based on the adolescents gender.

\begin{tabular}{|l|l|l|l|l|l|}
\hline Variable & $\begin{array}{l}\text { Nature of } \\
\text { Sample }\end{array}$ & N & Mean & $\begin{array}{l}\text { Standard } \\
\text { Deviation }\end{array}$ & C.R. value \\
\hline \multirow{2}{*}{ Self-esteem } & Males & 135 & 27.47 & 3.32 & \multirow{2}{*}{$3.58^{* *}$} \\
\cline { 2 - 5 } & Females & 119 & 29.00 & 3.45 & \\
\hline
\end{tabular}

$\mathrm{p}^{* *}<0.01$

Table shows the variable, sample size, and significance level in the Relationship between overall parenting and self-esteem among adolescent with Karl Pearson's coefficient of Correlation.

\begin{tabular}{|l|l|l|}
\hline \multicolumn{1}{|c|}{ Variables } & N & \multicolumn{1}{c|}{ C R Value } \\
\cline { 1 - 2 } Overall Parenting & 254 & $0.204^{* *}$ \\
\cline { 1 - 3 } Self-Esteem & 254 & \\
\cline { 1 - 3 }
\end{tabular}
$\mathrm{p}^{* *}<0.01$

Table Shows the variable, Nature of sample, sample size, Mean, Standard Deviation, ' $t$ ' value and Level of Significance on self-esteem between adolescents perception of mothering and fathering.

\begin{tabular}{|c|c|c|c|c|c|}
\hline Variable & $\begin{array}{c}\text { Parenting } \\
\text { Sample }\end{array}$ & N & Mean & $\begin{array}{c}\text { Standard } \\
\text { Deviation }\end{array}$ & C.R Value \\
\hline \multirow{3}{*}{ Self-Esteem } & Fathering & \multirow{2}{*}{254} & 376.96 & 54.8 & \multirow{2}{*}{$2.28^{*}$} \\
\cline { 2 - 4 } & Mothering & & 387.33 & 47.2 & \\
\hline $\mathrm{p}^{*<0.05}$ & & &
\end{tabular}

Table Shows the Variable, Nature of Sample, Sample size (N), Mean, Standard Deviation (SD), 't' value(C.R), and Level of Significance on self- esteem among the adolescent students on all the factors of mothering.

\begin{tabular}{|c|c|c|c|c|c|}
\hline Variable & Fathering Modes & $\mathbf{N}$ & Mean & SD & C.R. Value \\
\hline \multirow{16}{*}{ Self esteem } & Rejection & 154 & 27.68 & 3.39 & \multirow{2}{*}{$2.98 * *$} \\
\hline & Acceptance & 100 & 28.98 & 3.42 & \\
\hline & Carelessness & 89 & 27.70 & 3.65 & \multirow{2}{*}{$1.63 N S$} \\
\hline & Protection & 165 & 28.44 & 3.33 & \\
\hline & Neglect & 108 & 27.83 & 3.43 & \multirow{2}{*}{$1.41 \mathrm{NS}$} \\
\hline & Indulgence & 146 & 28.45 & 3.47 & \\
\hline & Utopian & 43 & 28.09 & 3.24 & \multirow{2}{*}{$0.199 \mathrm{NS}$} \\
\hline & Realism & 211 & 28.20 & 3.51 & \\
\hline & Lenient standard & 184 & 27.85 & 3.45 & \multirow{2}{*}{$2.53 *$} \\
\hline & Moralism & 70 & 29.05 & 3.33 & \\
\hline & Freedom & 92 & 28.09 & 3.46 & \multirow{2}{*}{$0.353 \mathrm{NS}$} \\
\hline & Discipline & 162 & 28.24 & 3.46 & \\
\hline & Faulty-Role Expectation & 169 & 27.85 & 3.28 & \multirow{2}{*}{$2.204^{*}$} \\
\hline & Realistic-Role Expectation & 85 & 28.86 & 3.72 & \\
\hline & Marital conflict & 144 & 27.52 & 3.27 & \multirow{2}{*}{$3.6^{* *}$} \\
\hline & Marital Adjustment & 110 & 29.06 & 3.51 & \\
\hline
\end{tabular}

$\mathrm{p}^{*}<0.05 \quad \mathrm{p}^{* *}<0.05 \quad$ NS not significant

(c) The International Journal of Indian Psychology, ISSN 2348-5396 (e)| ISSN: 2349-3429 (p) | 166 
Relationship between Perceived Parenting Skills and Self Esteem Among Adolescents

Table: Shows the Variable, Nature of Sample, Sample size (N), Mean, Standard Deviation (SD), ' $t$ ' value(C.R), and Level of Significance on self- esteem among the adolescent students on all the factors of fathering.

\begin{tabular}{|c|c|c|c|c|c|}
\hline Variable & $\begin{array}{l}\text { Nature of } \\
\text { Sample }\end{array}$ & $\mathbf{N}$ & Mean & $\begin{array}{l}\text { Standard } \\
\text { Deviation }\end{array}$ & $\begin{array}{l}\text { C.R } \\
\text { Value }\end{array}$ \\
\hline \multirow{16}{*}{ Self esteem } & Rejection & 122 & 27.63 & 3.33 & \multirow{2}{*}{$2.45^{*}$} \\
\hline & Acceptance & 132 & 28.99 & 3.50 & \\
\hline & Carelessness & 89 & 27.80 & 3.61 & \multirow{2}{*}{1.28} \\
\hline & Protection & 165 & 28.39 & 3.36 & \\
\hline & Neglect & 102 & 27.59 & 3.42 & \multirow{2}{*}{$2.24^{*}$} \\
\hline & Indulgence & 152 & 28.58 & 3.44 & \\
\hline & Utopian & 42 & 27.30 & 3.80 & \multirow{2}{*}{1.81} \\
\hline & Realism & 212 & 28.36 & 3.37 & \\
\hline & Lenient standard & 160 & 27.80 & 3.42 & \multirow{2}{*}{$2.35 *$} \\
\hline & Moralism & 94 & 28.85 & 3.44 & \\
\hline & Freedom & 113 & 28.06 & 3.40 & \multirow{2}{*}{0.52} \\
\hline & Discipline & 141 & 28.29 & 3.51 & \\
\hline & Faulty-Role Expectation & 167 & 28.08 & 3.27 & \multirow[b]{2}{*}{0.67} \\
\hline & $\begin{array}{l}\text { Realistic-Role } \\
\text { Expectation }\end{array}$ & 87 & 28.39 & 3.80 & \\
\hline & Marital conflict & 144 & 27.52 & 3.27 & \multirow{2}{*}{$3.6^{* *}$} \\
\hline & Marital Adjustment & 110 & 29.06 & 3.51 & \\
\hline
\end{tabular}

$\mathrm{p}^{*}<0.05 \quad \mathrm{p}^{* *}<0.01 \quad$ NS not significant

Table (Anova) - One Way Shows the Birth order, Sample size (N), Grouping, Sum of square, df, Mean square, $F$, and significance kevel of self-esteem of adolescence based on birth order.

\begin{tabular}{|c|c|l|l|l|l|l|}
\hline $\begin{array}{l}\text { Birth } \\
\text { Order }\end{array}$ & $\begin{array}{l}\text { Sample } \\
\text { Size (N) }\end{array}$ & Groups & $\begin{array}{l}\text { Sum of } \\
\text { Square }\end{array}$ & Df & $\begin{array}{l}\text { Mean } \\
\text { Square }\end{array}$ & F \\
\hline 1 & 141 & Between & 2.699 & 2 & 1.350 & \\
\hline 2 & 90 & Within & 3028.23 & 251 & 12.065 & .112 \\
\hline 3 & 23 & Total & 3030.929 & 253 & & \\
\hline
\end{tabular}

N S- not significant

Table -Anova (one way)Shows Occupation type, Sample Size, df, Mean square, F test, Significance Level of Self-esteem of adolescents based on occupation of father.

\begin{tabular}{|c|c|c|c|c|c|c|}
\hline $\begin{array}{l}\text { Occupation } \\
\text { Type }\end{array}$ & $\begin{array}{l}\text { Sample } \\
\text { Size }\end{array}$ & & & Df & $\begin{array}{l}\text { Mean } \\
\text { Square }\end{array}$ & $\mathbf{F}$ \\
\hline $\begin{array}{l}\text { Self } \\
\text { Employed }\end{array}$ & 51 & $\begin{array}{l}\text { Between } \\
\text { Groups }\end{array}$ & 39.274 & 2 & 19.637 & \\
\hline $\begin{array}{l}\text { White } \\
\text { Collar job }\end{array}$ & 72 & $\begin{array}{l}\text { Within } \\
\text { Group }\end{array}$ & 2991.655 & 251 & 11.919 & 1.648 \\
\hline $\begin{array}{l}\text { Blue collar } \\
\text { Job }\end{array}$ & 131 & Total & 3030.92 & 253 & & \\
\hline
\end{tabular}

NS not significant

(c) The International Journal of Indian Psychology, ISSN 2348-5396 (e)| ISSN: 2349-3429 (p) | 167 


\section{DISCUSSION SUMMARY}

(i) From the results it is observed that in general there is a overall difference in the level of selfesteem among adolescents.

(ii) Results reveal that there is gender difference among adolescents. It was found that selfesteem of girls was higher than that of boys. It may be because at this adolescent stage girls tend to be more attached to parents than boys who move away from parents in search of social identity.

(iii) The results show there is a positive relationship between parents and adolescent sample. It may be due to good parenting perceived by most of the adolescents. Other demographic variables may also been a factor.

(iv)There is a difference in adolescents' perception of parenting among father and mother. Mothering is of higher score than fathering. Adolescents at this stage may be more attached to mother than that of father. Father tends to be strict to adolescents than mother. Mothering score more due to the care they show towards children at home in care of their basic needs with more love and affection. Fathers' may not be able to express their love and care as mothers towards their children. Other factors of economic stress and work load may also act as a factor for inhibition to be close to children.

(iv) Results show there is difference in different modes of mothering and fathering as perceived by adolescents of both gender. Some modes are accepted to have an effect on adolescents' self-esteem. Results clearly indicate that the means of the various dichotomous modes show that positive styles have higher scores than the negative. So it clearly indicates that positive parenting enhances self-esteem of adolescents. Positive modes of father and mother has an impact on adolescents self-esteem.

(v) Results indicate there is no difference in self-esteem due to different birth order of adolescents. So this indicates that parents care towards children is equally perceived by children of various order of birth.

(vi) There is no difference in self-esteem of adolescents based on the occupation of their father. It may be due to overall parenting to have given the same effect to children in their selfesteem. The children of the school may not have difference of opinion in comparison with father's status based on occupation to have an effect on their self-esteem.

\section{SUMMARY AND CONCLUSION}

\section{Summary}

The present study was carried to find the relationship between perception of parenting skills and self-esteem among adolescents. Expost facto, non-experimental survey design was used for the study. Convenient random sampling of 254 samples, including 135 males and 119 females were selected from two schools in Chennai city. Tools used in the study were Parenting Scale by R.L. Bharadwaj, H. Sharma and A. Garg and the Rosenberg Self-Esteem Scale by Morris Rosenberg. The data was statistically analysed using SPSS version 19. Mean, Standard deviation, ' $t$ '-test, ANNOVA and Pearson's Correlation. The results were calculated and discussed. 


\section{Relationship between Perceived Parenting Skills and Self Esteem Among Adolescents}

\section{Conclusion}

From the above mentioned statistical inference the results revealed the following conclusions:

1. There is a significant difference in the self-esteem of adolescents based on gender.

2. There is a significant relationship between the self-esteem and parenting of adolescents.

3. There is a significant difference between overall parenting of father and mother of adolescence children.

4. There is a significant difference in the self-esteem of adolescence based on their perception of mothering under different modes as Rejection vs. Acceptance, Lenient Standard vs. Moralism, Faulty Role Expectation vs. Realistic Role Expectation, and Marital Conflict vs. Marital Adjustment.

5. There is a significant difference in the self-esteem of adolescence based on their perception of fathering under different modes as Rejection vs. Acceptance, Neglect vs. Indulgence, Lenient Standard vs. Moralism, and Marital Conflict vs. Marital Adjustment.

6. There is no significant difference in the self-esteem of adolescents between $1^{\text {st }}, 2^{\text {nd }}$, and $3^{\text {rd }}$ birth order.

7. There is no significant difference in the self-esteem of adolescents whose fathers' occupations are categorised as self-employed, or white collar job, or blue collar job.

\section{LIMITATION OF THE STUDY}

- The major limitation of this study is, it was done with a small population only in urban area (Chennai).

- Less time was allocated for data collection.

- The Sample is selected based on convenience and was randomly assigned

- The data has a lack of parents' report of their parenting styles.

- Other causal factors such as teachers influence, friendship, personality etc. which affects self-esteem were not considered.

\section{SUGGESTIONS FOR FUTHER STUDY}

- Similar study could be done with large sample.

- A similar study could be done with the inclusion of parents of special children.

- Intervention Training programmes can be given to enhance adolescents' self-esteem at the early stage of adolescence

- Intervention programmes can be organized for parents to enhance parenting skills especially with adolescent children.

\section{Acknowledgments}

The author appreciates all those who participated in the study and helped to facilitate the research process. 


\section{Conflict of Interests}

The author declared no conflict of interests.

\section{REFERENCES}

Abdorreza, k.(2015). Parental Parenting Attitude and Style and Its Effect on Children's School Achievement..Department of Human Development \& Family Studies, Faculty of Human Ecology. University Putra Malaysia. Retrieved from http://www.ccsenet.org/journal/index.php/ijps/article/viewFile/6158/6380/

Ahmad, A., Irshad, H., and Muhammad, W.T. (2014). A Study On Impact Of Parenting Styles And Self-Esteem On Academic Achievement Of Postgraduate Students. Retrieved from https://www.researchgate.net/publication/280464413

Alaina, E. Boyle, K. E., Bigelow, K. A. L., Lorraine, C. T. and Melissa, D. R. (2015 OCT). Journal of Child and Family Studies. 14 January 2015. Volume 24, Issue 10, pp 30303037. Retrieved from http://link.springer.com/article/10.1007/s10826-014-0106-2

Alastair, H. L., Edward, M., Helena, R., Jacqueline, B., and Jay, B. (2006 JUNE 22). Effects of Sure Start local programmes on children and families: early findings from a quasiexperimental, cross sectional study. National Evaluation of Sure Start Research Team (2006 MAY 9). Retrieved from http:/www.bmj.com/content/332/7556/1476?hrss=1

Ali, A., Fateme, H., Fateme, P., Leila, S. M., and Shahla, K. (2014 APRIL).Adolescents' SelfEsteem in Single and Two-Parent Families. Community Based Nurs Midwifery. Iran. 2014 Apr; 2(2): 69-76. Retrieved from http://www.ncbi.nlm.nih.gov/pmc/articles/PMC4201193/

Akanksha, D., and Mamta, C. (2013).Parenting Styles and its Effects on Adolescents' SelfEsteem. Retrieved from http://ijiet.com/wp-content/uploads/2013/09/42.pdf

Akila,R., Mercinah, R., and Nirmala, D.(2010). A Study On Academic Performance, SelfEsteem and Hopelessness of Higher Secondary School Students. Retrieved from http://www.academia.edu/8058131

Akse. J., Benjamins, C., Dick, K., Guzman, N.V., and Restifo (2009MAR). A Pilot Study Of Self-Esteem As A Mediator Between Family Factors and Depressive Symptoms In young adult university students. Retrieved from http://family-wise.org/wp-content/uploads/2013/08/RestifoAkse09.pdf

Ambika, K., and Cheryl, B. (2004 FEB 27). Interparental Conflict and Parenting Behaviors: A Meta-Analytic Review. Family Relations. Volume 49,( Issue 1), pg 25-44, 2000 January

Anita.C, and Suman.B (2008). Role of Parenting Style in Adjustment of High School Children. Faizabad, Uttar Pradesh, India. Retrieved from www.krepublishers.com/...PDF Davies, M. (2000).The Blackwell encyclopedia of social work. Wiley-Blackwell. p. 245, ISBN 978-0-631-21451-9.

Arun, P.M.(2012 JUN 28). A Correlation Study To Assess The Influence Of Parenting Style And Academic Achievement Among Adolescent Students Of Selected Pre-University Colleges In Gokak Taluka. Retreived from 


\section{Relationship between Perceived Parenting Skills and Self Esteem Among Adolescents}

http://sensoria.swinburne.edu.au/index.php/sensoria/article/download/71/100\& ved

Ary, D.V.,Biglan, A., Irvine, A. B., Metzler, C. W., and Smolkowski, K. (2012). The effectiveness of a parenting skills program for parents of middle school students in small communities. Journal of Consulting and Clinical Psychology, Vol 67(6), Dec 1999, (811825). Retrieved from http://www.ncbi.nlm.nih.gov/pubmed/10596504.

Asare, D.,andSamuel, A.,( 2012). The Effects of Parenting on the Self-Esteem of Adolescents. Winifred Department of Psychology, University of Ghana. Vol2, No 11. Retrieved from http://www.iiste.org/Journals/index.php/RHSS/article/view/3784.

Atefoe.A, Kugbey. N, and Mawullkem. E. K (2014NOV). Adolescents' Self-esteem and Academic Achievement in Ghana: The Role of Parenting Styles and Sex Differences. Retrieved from https://www.researchgate.net/.../274073863_Adolescents

Batangass, M., and Dalisay, G. (2014). Parenting Styles And Self-Esteem Among Criminology Students Of Lyceum Of The Philippines University. Retrieved from http://research.lpubatangas.edu.ph/wp-content/uploads/2014/08/GSR

Carlos.et al. (2005, SEP 8). Relations Among Positive Parenting, Children's Effortful Control, and Externalizing Problems: A Three-Wave Longitudinal Study. Retrieved from www.ncbi.nlm.nih.gov > NCBI > Literature > PubMed Central (PMC)

Caroline, W. C., Chrissie, V., Deborah, Mc N. and Sam, C.H. D. (2005 JUN 20). Parenting Skills Training: An Effective Intervention for Internalizing Symptoms in Younger Children. Retrieved from http://www.ncbi.nlm.nih.gov/pubmed/ 15966947

Chiu-Hui,L., (2004). Relationships among socio-economic status, parenting, academic achievement, and Self-esteem in early and middle adolescence: a longitudinal study. Retrieved from http://lib.dr.iastate.edu/cgi/viewcontent.cgi?article=2176\&context=rtd

Choi, S. L., Ooi, S.H., and Rabeatul, H. A. R.,(2015 AUG). Mediterranean Journal of Social Sciences MCSER Publishing, Rome-Italy.Vol 6 No 4 S3.Retrieved from http://www.mcser.org/journal/index.php/mjss/article/viewFile/7291/6980.

David, W., John, R. L., and Ronit, M. Gershater, M. (2003 DEC). Project Safe Care: Improving Health, Safety, and Parenting Skills in Families Reported for, and At-Risk for Child Maltreatment. Journal of Family Violence. Volume 18, Issue 6, pp 377-386. Retrieved from http://link.springer.com/article/10.1023/A:1026219920902.

Deborah, J. L., Gustavo, C., and Scott, C. R. (2004)."Pathways to Self-Esteem in Late Adolescence: The Role of Parent and Peer Attachment, Empathy, and Social Behaviors".Journal of Adolescence 27:6(2004DEC), pp. 703-716.Retrieved from http://digitalcommons.unl.edu/psychfacpub/315

Elenora, G., Lara, H.,(1999). The Relationship between Self-Esteem and Parenting Style. A cross-cultural comparison of Australian and Vietnamese Australian Adolescents. Retrieved http://m.jcc.sagepub.com/content/30/6/742.abstract.

Eva L. E.(1999), Introduction to Early Childhood Education, parents-attitudes and beliefs. University of Nevada, Reno.3rd edition. Delmar Publishers..ISBN 0-7668-0048-2. 


\section{Relationship between Perceived Parenting Skills and Self Esteem Among Adolescents}

Frances, G., Ivana, K. and Jennifer, B. (2006 NOV 1) did a study on Randomised controlled trial of a parenting intervention in the voluntary sector for reducing child conduct problems: outcomes and mechanisms of change. Retrieved from http://psycnet.apa.org/journals/ccp/67/6/811/

Garcia, Martinez I (2012JUN 28). The Relationship Between Parenting Styles and Self-Esteem Among Brazilian Adolescents. Retrieved from www.rguhs.ac.in/cdc/onlinecdc/uploads/05_N058_41439.doc

Gonzalez (2001).The Relationship of Authoritative and Authoritarian Parenting by Gender And Race. Retrieved from https://books.google.co.in/books?isbn=0549792708

Hamidreza, Z., Maryam, K. (2011 DEC 17).Parenting Styles and Self-esteem. Retrieved from http://www.sciencedirect.com/science/article/pii/S1877042811027637

Jan, M. N., Katherine, S., Melissa, W., and Pollyanna, H. (2007 DEC).Preschooler Obesity and Parenting Styles of Mothers and Fathers: Australian National Population Study. American Academy of Paediatrics VOLUME 120 / ISSUE 6. Retrieved from http://pediatrics.aappublications.org/content/120/6/e1520.short

Jari-Erik, N., and Kaisa, A. (2005 FEB 2005).The Role of Parenting Styles in Children's Problem Behavior. Child Dev. 2005 Nov-Dec;76(6):1144-59. PubMed PMID: 16274431. Retrieved from http://www.ncbi.nlm.nih.gov/pubmed/16274431

Joshi, S. ,Rekha, S. (2009).The self-esteem and academic achievement of adolescents. Varanasi. Journal of the Indian Academy of Applied Psychology October 2009, Vol.35, Special Issue, 33-39. Retrieved from medind.nic.in/jak/t09/s1/jakt09s1p33.pdf

Kishore K., Pandey.R.C, and Rai.R.N (2009).Perceived Parental Rearing Style and Personality among Khasi Adolescents. Journal of the Indian Academy of Applied Psychology. Shillong-Nawada( October 2009). Vol. 35, Special Issue, pp 57-60 . Retrieved from http://medind.nic.in/jak/t09/s1/jakt09s1p57.pdf.

Koblinsky, S. A.; Katherine. K. A.; Randolph, S. M. (2006 OCT).Social skills and behavior problems of urban, African American preschoolers: Role of parenting practices, family conflict, and maternal depression. American Journal of Orthopsychiatry, Vol 76(4), Oct 2006, 554-563. Retrieved from http://dx.doi.org/10.1037/0002-9432.76.4.554.

Kugbey.N, Mawulikem.E.K et al.,(2015). Adolescents' Self-Esteem and Academic Achievement in Ghana: The Role of Parenting Styles and Sex Differences. Retrieved from www.sciencedomain.org

Lee,Y.C., (2011 APRIL). A study of Relationship Between Parenting Styles And Self-Esteem .Self-Esteem's Indicator - Parenting Styles. Retrieved from http://eprints.utar.edu.my/278/1/PY-2011-0802154.pdf

Lucy, C.(2013). Parenting Styles and Self-Esteem. Retrieved from http://scholarship.claremont.edu/cgi/viewcontent.cgi?article=1158\&conte

Manisha, B. (2014). Child issues in Applied Psychology.ABD publishers. Jaipur. New Delhi. ISBN: 978-81-8376-459-9 


\section{Relationship between Perceived Parenting Skills and Self Esteem Among Adolescents}

Mariji, S., and Zora, R.(2014SEP). Relations of Parenting Styles and Friendship Quality to SelfEsteem, Life Satisfaction and Happiness in Adolescents. Applied Research in Quality of Life(2014JUL), Volume 9, Issue 3, pp749- 765. Retrived from http://link.springer.com/article/10.1007\%2Fs11482-013-9268-0

Mimi, C. (2007). Cultural Differences in Parenting Styles and their Effects on Teens' SelfEsteem, Perceived Parental Relationship Satisfaction, and Self-Satisfaction. Retrieved from repository.cmu.edu > cgi > view content

Nancy ES (2008 MAY). The Relationships Between Parenting Style, Academic Self-Efficacy and College Adjustment Of Freshman Engineering Students. Retrieved from http://digital.library.unt.edu/ark:/67531/metadc6054/m1/9/

Nicola S. S., and Tamra J. S.(2006). Emotional Intelligence and Self-Esteem Mediate Between Perceived Early Parental Love and Adult Happiness. Retrieved from www.researchgate.net/publication/228476737

Preethi.C, and Rosa MC (2012). A Study On Parenting Styles In Relation To Stress And SelfEsteem. Retrieved from http://ijter.com/pdf\%20files\%20folder/DECEMBER2012/P1.pdf

Quarles,V. (2012). A study of parenting authority styles and self-esteem: Implications for families. Capella University. (129 pages). Retrieved from http://gradworks.umi.com/35/18/3518447.html

Rosenberg Self-Esteem scale interpretation. Retreived from http://www.growing-selfesteem.com/rosenberg-self-esteem.html

Saira, Y.,(2015).The Relationship between Self-esteem, Parenting Style and Social Anxiety in Girls.(Pakistan). Retrieved from files.eric.ed.gov/fulltext/EJ1083862.pdf

.Sathyabama.B, and Jeryda Gnanajane. J. O (2014. AUG). Perceived Parental Attitude and Self Esteem of Adolescents. IOSR Journal Of Humanities And Social Science (IOSR-JHSS) Volume19, Issue8, Ver.V (Aug.2014), PP01-04. Retrieved from http://www.iosrjournals.org/iosr-jhss/papers/Vol19- issue8/Version-5/A019850104.pdf

Wayne,W., Margaret, A. L. (2007)Psychology Applied to Modern Life. Adjustment in 21st century. Thomson Delmar Learning. India. ISBN: 81-315-0196-5. Eighth edition.

How to cite this article: Niraja S, Meherunissa S (2016), Relationship between Perceived Parenting Skills and Self Esteem Among Adolescents, International Journal of Indian Psychology, Volume 4, Issue 1, No. 81, ISSN:2348-5396 (e), ISSN:2349-3429 (p), DIP:18.01.137/20160401, ISBN:978-1-365-59365-9 